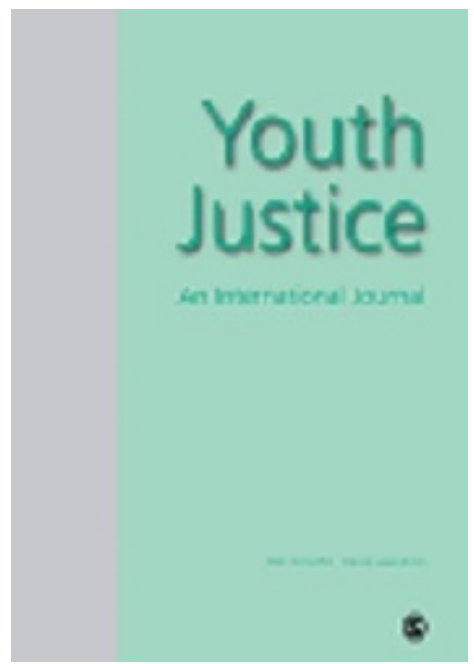

\title{
The Pains and Gains of COVID-19 - Challenges to Child First Justice in the Pandemic
}

\begin{tabular}{|c|l|}
\hline Journal: & Youth Justice \\
\hline Manuscript ID & YJJ-21-0031.R1 \\
\hline Manuscript Type: & Original Article \\
\hline Keywords: & $\begin{array}{l}\text { COVID-19, Youth justice, England and Wales, Youth Justice Board, Youth } \\
\text { Offending Teams, Child First youth justice, Youth criminalisation, solitary } \\
\text { confinement, Engagement, Children's rights }\end{array}$ \\
\hline Abstract: & $\begin{array}{l}\text { The global COVID-19 pandemic has particularly affected justice-involved } \\
\text { children. Youth justice policy changes and innovations have assisted } \\
\text { communication and engagement with these vulnerable children during } \\
\text { unprecedented times, whilst attempting to limit risks of contagion and } \\
\text { criminalisation - all central tenets of the 'Child First' guiding principle for } \\
\text { have enhanced the experiences of some justice-involved children } \\
\text { (gains), others have disproportionately disadvantaged justice-involved } \\
\text { children in court, community and custody contexts (pains), increasing } \\
\text { criminalisation, disengagement and anxiety. These pains of COVID-19 } \\
\text { have effectively eroded the rights of this already-vulnerable group of } \\
\text { children. }\end{array}$ \\
\hline
\end{tabular}

\section{SCHOLARONE ${ }^{m}$ Manuscripts}




\section{Introduction}

Just over a century since the outbreak of Spanish flu in 1918, which claimed at least 40 million lives (Pitt, 2018), the world is challenged by another global pandemic - COVID-19. The UK has been hard hit by the COVID-19 pandemic, which has, up to December 2021 seen over 10 million people test positive, almost 600000 resultant hospital admissions and towards 168 000 deaths (with COVID-19 on the death certificate) (UK Government, 2021). Across all policy areas, significant changes have been made for public safety and youth justice is no exception. Children in the Youth Justice System (YJS) are already among the most vulnerable in society, likely to have experienced significant adverse childhood experiences like abuse and neglect, on top of structural disadvantages like child poverty (Yates, 2010). Research has shown that they are doubly disadvantaged by becoming enmeshed in an iatrogenic inherently damaging system, adding criminalisation to their already-significant difficulties (McAra and McVie, 2007; XXX, 2015). Recent policy directives in England and Wales from the Youth Justice Board ${ }^{1}$ (YJB) have emphasised that children should be treated as children first, privileging their child status over any offender-related identity (a defining aspect of the 'Child First' justice paradigm, hereafter referred to as 'Child First'; YJB, 2021a). Central to Child First justice is a series of underlying evidence-based practice principles (XXX, 2021) which have been significantly challenged by COVID-19: seeing children as children, developing a prosocial identity for positive child outcomes, collaborating with children, promoting diversion (YJB, 2021a). The Child First paradigm is underpinned by the 'Child Friendly Justice' recommendations of several prominent international children's rights instruments, focusing primarily on protection, provision and participation for children in youth justice systems (Goldson, 2014; see also XXX, 2021).

The Committee on the Rights of the Child (The Committee) foresaw that both COVID-19 and measures put in place to mitigate its effects would create new safeguarding risks and exacerbate already existent ones (United Nations/UN, 2020). This acknowledges that all children will have been adversely affected - vulnerable for their child status. Global action included widespread school closures and 'stay at home' orders which severely hampered

\footnotetext{
${ }^{1}$ The YJB oversees youth justice practice in England and Wales, delivered through agencies such as the police, courts, custodial institutions and at through multi-agency (comprising health, education, social services, police and probation) Youth Offending Teams (YOT), established through the Crime and Disorder Act 1998
} 
their right to leisure and play possibilities, especially for those without outside space. Children reported serious difficulties in maintaining friendships during lockdown, vital for social development (Lundy et al., 2021). The Committee emphasised that 'all decisions and actions concerning children must be guided by the principle of the best interests of the child, and children's rights to life, survival, and development, and to be heard' (UN, 2020: 2). UNICEF research has shown that the pandemic has caused major disruption to youth justice processes worldwide, severely affecting some children's access to justice (UNICEF, 2021). However, the same research also highlighted innovations which have improved the plight of children involved the justice system, including that 11,600 children across 37 countries have been released from custody directly through pandemic-mitigating policies (UNICEF, 2021). Our contention is that children involved in the justice system in England and Wales (in common with elsewhere, cf. Lynch and Kilkelly, 2021) are additionally damaged above normallyvulnerable children through ill-thought-out responses (both general and justice-related) to the COVID-19 pandemic creating triple disadvantage and effectively foregrounding their offender status, in clear conflict with Child First justice.

This article explores policy and legislative developments concerning the COVID-19 pandemic in the YJS of England and Wales within a Child First context, analysing pains and gains of COVID-19. In what ways have children involved in the justice system benefited from innovative thinking borne of necessity (gains of COVID-19); and how, through their triple disadvantage, have they been disproportionately disadvantaged, fostering disengagement from support processes and exacerbating potential harm (pains of COVID-19)? We identify erosions/negations of children's rights as detailed in the United Nations Convention on the Rights of the Child (UNCRC), to which the United Kingdom (UK) is a signatory State, considering those arising from the pandemic itself (some of which are common to all children), but particularly concentrating on those caused (or exacerbated) by poor policy and implementation within youth justice specifically. For this analysis, Sykes' (1958) 'Pains of imprisonment' conceptualisation will be repurposed, expanding Bateman's (2020) application to the effects of COVID-19 on children in custody to encompass children at every stage of the YJS, from prevention to custody and resettlement, using it to measure harms from COVID-19 (and resultant policies) on this vulnerable group. After looking at the effects on courts, attention will turn to two specific aspects of the YJS: community contact and custody; applying 
to both subthemes of innovation, contact, access, safeguarding, engagement and children's rights; all considered through the overarching lens of Child First justice.

\section{Child First Justice}

The 'Youth Justice Review' conducted by Charlie Taylor in 2016 recommended 'a new system in which young people are treated as children first and offenders second' (Taylor, 2016: 48). Thereafter, following Taylor's appointment as Chair, the Youth Justice Board (YJB) for England and Wales adopted the 'Child First' principle as their central strategic objective. Similarly, Child First strategic developments were developed in related policy areas, including:

- Policing - The National Police Chiefs' Council (NPCC) 'Child Centred Policing' national strategy document stated that "It is crucial that in all encounters with the police those below the age of 18 should be treated as children first' (NPCC, 2015: 9)

- Courts - The Sentencing Council's guidelines established that for children 'the approach to sentencing should be individualistic and focused on the child or young person, as opposed to offence focused' (Sentencing Council, 2017: 4).

The centrality of Child First within national youth justice policy/strategy was reinforced in the YJB Business Plan 2021-22, which detailed the vision for 'A Child First youth justice system' (YJB, 2021a: 2) and prioritised in the Vision Statement of the YJB Strategic Plan 2021-2024, which commits to Child First as the 'strategic approach and central guiding principle' (YJB, 2021b: 3). The Plan operationalises Child First into four inter-related 'tenets' (YJB, 2021b: 1011), themselves an amalgamation of key features of the Positive Youth Justice ${ }^{2}$ model (XXX, 2015) and Constructive Resettlement ${ }^{3}$ (Hazel and Bateman, 2021; Hazel et al., 2017):

\footnotetext{
2 The YJB's definition incorporates Positive Youth Justice concepts of child-focused practice, future-focused promotion of positive behaviours/outcomes, engagement, supportive relationships and diversion from the formal YJS. However, it does not explicitly include promoting children's entitlements (maximum outcomes) rather than rights (minimum standards), evidence-based partnership, legitimacy and 'responsibilising' adults rather than children's (see XXX, 2015).

${ }^{3}$ Five principles characterise successful, 'constructive' resettlement programmes for children leaving custody: Constructive - strengths based, and future-focused on identity shift and empowering positive choices; Cocreated - inclusive of the child, their family and supporters; Customised - individualised wraparound support, incorporating diversity; Consistent - agencies immediately focus on resettlement $t$, enabling seamless transitions; Co-ordinated - managed widespread partnership across agencies and sectors (Hazel et al., 2017; see also YJB, 2018).
} 
1 Seeing children as children: Prioritise children's best interests, recognising their needs, capacities, rights and potential. All work is child-focused, developmentally informed, acknowledges structural barriers and meets responsibilities towards children.

2 Develop pro-social identity for positive child outcomes: Promote children's individual strengths and capacities to develop their pro-social identity for sustainable desistance, leading to safer communities/fewer victims. All work is constructive and future-focused, built on supportive relationships empowering children to fulfil their potential and contribute positively to society.

3 Collaboration with children: Encourage children's active participation, engagement and wider social inclusion. All work is a meaningful collaboration with children/their carers.

4 Promote diversion: Promote a childhood removed from the justice system, using preemptive prevention, diversion and minimal intervention. All work minimises criminogenic stigma from system contact.

The YJB's emphasis of Child First as the guiding principle for youth justice practice was originally articulated in 2019, providing a 'framework for youth justice practice' and the 'minimum expectation for all agencies' to ensure that positive outcomes for children align (MoJ/YJB, 2019: 3). These revised 'national standards' for practitioners are, therefore, 'indicative of a clear distinction between the philosophy now espoused by the YJB [Child First] and that which informed the previous iteration of the standards [risk management]' (Bateman 2020: 4). The new expectations for Child First practice were consolidated in the YJB 'Case Management Guidance' for practitioners (currently under revision), which are separate guidance documents outlining how practitioners and managers should work with children at different stages of the YJS (YJB, 2019).

\section{Initial COVID-19 restrictions within the YJS}

As the UK entered the first national 'lockdown' on 23 March $2020^{4}$ (BBC, 2020), the Ministry of Justice $(\mathrm{MoJ})^{5}$ made several systemic restrictions, policy changes and support mechanisms 


\footnotetext{
${ }^{4}$ For example, all but essential shops and services closed (including schools), citizens generally had to stay at home, only key workers could work outside the home.

${ }^{5}$ The Ministry of Justice is a department of the UK Government with responsibility for the justice system (adult and child) to which the YJB ultimately answers.

${ }^{6}$ The Youth Custody Service (YCS) was established with overall responsibility for youth custody in England and Wales (Youth Custody Improvement Board, 2017), following evidence of custodial establishment mismanagement and neglect of custodial objectives by the YJB.

7 One of the YJB's aims is to support effective practice, and to this end have set up a 'Resource Hub' on which YOT innovations are showcased to share what is deemed as good practice more widely; see https://yjresourcehub.uk/
} 
throughout the sector (potentially representing gains of COVID-19), children have been disproportionately disadvantaged by the effects of isolation at a sensitive developmental point when they most require socialisation (Bateman, 2020). Therefore, children involved in the justice system, often socially excluded and disproportionately from the lower socioeconomic echelons of society and enmeshed in a criminalising system, are triply disadvantaged, suffering the 'pains of COVID-19' (Bateman, 2020) far more than other children. This has elevated their 'offending status' over their 'child status', to the expense of fledgling Child First practice, and threatened their rights as children (UN, 1989).

In the YJS, the 'pains and gains' of lockdown experienced by children were partly catalysed by significant retrenchment of court activity, severely limiting (timely, consistent, reliable) access to justice for children, as most court activity was suspended in the initial lockdown. Whilst indications were that 'virtual courts' (a lockdown-related innovation) would be developed to facilitate the swift resumption of trials, in reality this ambition has not been realised (House of Commons Justice Committee, 2020a). This exacerbated existing delays in children's access to timely justice ('justice delayed is justice denied'; Sleight, 2020) and access to potentially supportive interventions (e.g. Child First interventions prioritising positive outcomes, rather than criminalisation) that can result from court-based mechanisms of justice. It was not until in-person trials were recommenced in May 2020 that those awaiting trial could have their matters tabled. By the end of June 2020, the backlog of children awaiting court dates was 55\% up on 2019 (HMIP, 2020a: 15). A concern particularly relevant to children awaiting trial is the difference made if they turn 18 years of age after the offence but before their first court appearance, as they protections afforded to children in the YJS being then sentenced as adults, with consequential increases in sentencing tariffs and longer rehabilitation periods before sentences are considered 'spent' for such purposes as job applications (Harris and Goodfellow, 2021). Children who might previously have begun sentences supervised by YOTs (and in some cases remaining with them due to vulnerability concerns) would begin with the adult-orientated probation service, with adult-centric sentences addressing child-centric behaviour.

Where remote hearings were facilitated by video link appearances, concerns have been raised regarding whether this adversely affects a child's access to justice and a fair trial, as it could severely impair their ability to effectively participate in proceedings. This is exacerbated if the 
'innovative' use of technology (paradoxically) delays court proceedings. Lack of access to a physically-present lawyer could increase anxiety and reduce their understanding of (distant) non-verbal cues. This might increase the chances of children responding in a way which appears inappropriate, affecting fairness, potentially compounded by higher-than-average rates of learning and communication difficulties for children involved in the justice system (House of Commons Justice Committee, 2020b: 19).

The suspension of most court activity also prevents orders being returned to court for early revocation due to good progress, commonly used by YOTs to acknowledge and reward positive engagement and progress (a Child First objective). This not only prolongs children's involvement with inherently damaging youth justice agencies, (McAra and McVie, 2007), but is a delay to justice, effectively increasing criminalisation. This again impacts on time periods before which convictions can be considered 'spent' as children whose order is not revoked, when in pre-pandemic circumstances it would have been, will have to declare their criminal record for longer on application forms (potentially reducing their employability at a time when pandemic-related youth unemployment specifically is increasing problematic; ONS, 2020). These court-related delays to justice do more than simply disengage and potentially (further) criminalise the child, they risk contravening several elements of the UNCRC, notably prioritising children's best interests (Article 3), avoiding of inhumane treatment (Article 37) and ensuring that children in juvenile justice systems are treated with dignity and respect (Article 40).

Taken together, continued delays in court proceedings, whether caused or exacerbated by lockdown measures, including failure to properly execute technological innovations (e.g. virtual courts), have coalesced to adversely affect children's access to justice and their access to supportive interventions in the community (as will be discussed). These delays have served to disengage children and risk further criminalisation, threatening their rights in several key areas. Court-induced 'pains' of COVID-19 are tangible, whereas court-related 'gains' have been less evident or compelling.

\section{The pains and gains of COVID-19 in the community}


Children involved in the justice system in the community face a range of challenges, exacerbated by COVID-19 and related policies. This risks effective outworking of emerging Child First practice by YOTs before it is properly embedded, threatening retrenchment to previous risk-led working and decision-making. Using this lens, the discussion now focuses on issues affecting these children in the community (voluntary or statutory interventions), in relation to contact with/access to them, benefits and risks of developing innovations to overcome difficulties like social distancing, arising safeguarding issues and potential effects of all this on their UNCRC rights (UN, 1989).

Children's first contact with YOTs is generally through prevention programmes (preventing them becoming further justice-involved), then through measures to divert them formal court disposals to avoid criminalisation for low level initial offending, and eventually court-ordered contact post-conviction (court orders) generally involving assessment, supervision, and postcustody re-entry/resettlement, where the greatest likelihood of reoffending lies (MoJ, 2020c). The principle of 'engagement' with (also understood as belief in, motivation for, commitment to; avoiding definitions based on mere attendance) youth justice support services is central to Child First justice and effective pursuit and realisation of preventative, supervisory/protective and supportive aims in the community (cf. XXX, 2015). YOTs adapted quickly and effectively to lockdown restrictions through innovative practice developments, but wider issues of system delay remain (see previous section), which fosters children's disengagement from youth justice processes, also potentially resulting in loss of justice (Sleight, 2020) and increasing criminalisation (through process interruption or COVID-19specific police action), all of which moves away from actualising Child First in practice.

\section{Contact and access}

Where children engage fully with YOT practitioners (e.g. regular contact, building supportive relationships; XXX) and interventions (including participating meaningfully in design and delivery), youth justice in the community is far more likely to be successful (and Child First; $X X X, 2015$ ). However, YOTs' retraction to minimum statutory delivery (due to staff working from home and minimisation of face-to-face contact - see later) appears to have meant that in some areas prevention services - non-criminalising voluntary support or pro-social programmes to help children develop interests and skills to prevent offending in the future through the development of a pro-social identity - have been deprioritised or suspended (cf. 
Wrexham Youth Justice Service, 2020; Ealing Integrated Youth Service, 2020). Unfortunately, nationally it is currently impossible to compare since no inspection or YJB reports on COVID19 practice even mention non-statutory work. This retraction might partly have been due to restrictions on activities, but the loss of this vital prevention work to stop children from ever entering the (criminogenic/iatrogenic) YJS could potentially reverse the trend of the past decade (as prevention has developed) of reducing first time entrants to the system (Ministry of Justice/YJB, 2021). Potentially the Child First tenet of prioritising diversion from contact with youth justice services could be better served by prevention being offered within noncriminal agencies like youth services, but cuts over the past decade have seen these contract to a fraction of their previous size, meaning they are unlikely to plug any gaps (YMCA, 2020).

On a statutory level, children involved in the justice system receiving court-ordered community disposals (or diversionary police outcomes, for example Youth Conditional Cautions) are typically supervised by YOT practitioners. This practitioner-child relationship provides the keystone to effectiveness and truly Child First practice, as without it, children are less likely to engage meaningfully, and ultimately to desist from crime (Johns et al., 2017; XXX, 2015). Those not engaging sufficiently with the YOT can be returned to court for resentencing, sometimes even risking custody. YOTs have made enthusiastic use of telephone contacts or video apps leading to many children keeping YOT appointments through these media (YJB, 2020c). Although this has facilitated YOTs to maintain appointments with children where this might otherwise not have been possible, negatively it might adversely affect children's engagement ability should they find this kind of contact difficult, thereby increasing risk of further (or deeper) criminalisation negating Child First practice.

\section{Innovation - benefits and risks}

The strictures of lockdown encouraged YOTs to rethink strategies. As the YJB Resource Hub shows, this resulted in innovative and creative work facilitating essential work to continue (YJB, 2020d), resulting in some gains of COVID-19 for children involved in the justice system. The inspection report on YOT activity during the pandemic particularly praised the use of such strategies as 'walk and talk', bike rides and allotments for contact between children and workers (HMIP, 2020a: 20). It is encouraging that the inspectorate saw these developments as positive, since such positive-focused activities hold real promise in the actualising of Child First justice into practice. 
To ensure that Referral Orders ${ }^{8}$ could continue, community panel meetings became virtual, facilitated through video conference, but this risks reducing the ability or opportunity for a child to make meaningful inputs into their own plan, losing the important Child First tenet of meaningful collaboration with children. Indeed, panel members have expressed concerns about the virtual platform, telling HMIP (2020a: 20) that they 'couldn't really get a sense of the child and too much was lost in not being able to see the non-verbal communication and dynamics between children and their parents and carers'. Informal conversations with YOT staff showed that some children benefited from contacts facilitated through video calls, seeming to prefer to 'meeting' workers virtually resulting in better engagement (a gain), possibly ushering in the new world of digital working as envisioned by Barn and Barn (2019). This was echoed in the inspection, which found that both children and their families reported virtual contact as "less intense and 'scary" (HMIP, 2020a: 22). However, staff also acknowledged that others may have found this more challenging, with one YOT practitioner noting that some children became difficult to track down, assisted by uncooperative parents, thereby risking breach action (instigated at the behest of managers trying to straddle a riskapproach and newer Child First thinking). This is exacerbated by digital poverty, more in evidence with children involved in the justice system than generally (HMIP, 2020a). There are wider digital poverty effects in education, since being justice-involved was absent from the definitions of 'vulnerability' which allowed access to face-to-face education, after lockdownenforced school closures (HMIP, 2020a). Lack of internet access or technology hardware adds not only to the challenge of education access, but also to the ability of workers in making meaningful contact with children, potentially reducing this to merely 'checking in' rather than facilitating engaging work or building good relationships, again negating the development of Child First practice. If work with children involved in the justice system is to be truly digitalised, then issues of digital poverty must be addressed.

\section{Safeguarding}

YOTs take safeguarding responsibilities seriously, given that children involved in the justice system are more likely to have experienced abuse and neglect than the general population

\footnotetext{
8 Referral Orders, designed as the first official court disposal for a child from the Youth Justice and Criminal Evidence Act 1999, require a community panel to be convened to begin the order, and at various points throughout, ending with an end of order review panel.
} 
(Zettler, 2021), motivating workers to maintain face-to-face contact wherever necessary (despite risks to themselves; YJB, 2020c). However, the need for this may not always be evident since another potential unintended consequence of phone-based contact is reduced opportunity for children experiencing abuse at home to make disclosures to YOT staff, for fear of either being overheard, or through the necessity of using the parent's handset (children sometimes find maintaining phone ownership difficult through loss, theft, or temptation to sell). This could increase vulnerability levels when family difficulties (a frequent feature for children involved in the justice system) are already exacerbated by enforced and unavoidable increased time within family households during lockdown. It is likely, therefore, that phoneonly contact will impact the quality of relationships between workers and children, potentially risking engagement breakdown. Despite the heightened potential for mental health difficulties due to restrictive policies, access to agencies aimed at mitigating this became acute. Substance misuse and health appointments (including mental health) appeared to be facilitated entirely often through phone contact, raising significant concerns about effectiveness (cf Wrexham Youth Justice Service, 2020).

\section{Children's Rights}

COVID-19 restrictions not only impede Child First justice, but also, threaten rights of children more generally, as identified in the UNCRC (UN, 1989), with the lockdown requirement to 'stay at home' potentially constituting a breach of UNCRC Article 37 - deprivation of liberty. The various policy changes, especially considering safeguarding issues outlined above, also threaten the basic tenet of 'best interests' (Article 3), which surely cannot be maintained through depleted contact with support agencies (mental health, substance misuse - also threatens Article 24 regarding rights to healthcare), complete absence of prevention activity, or virtual-only contact with YOTs. The right for a child's voice to be heard and given 'due weight' (Article 12) is threatened by deficiencies within 'innovative' online systems, especially when used in decision-making (for instance a Referral Order Panel). Article 28, a child's right to education, is potentially restricted due to lack of alternatives during lockdown for children unable to access online learning through digital poverty; those not currently in education are unlikely to feature in mitigating actions from education authorities, increasing the likelihood of them slipping through the net. Delayed justice due to closed courts impacts on the outworking of Article 40, which stresses that children should 'have the matter determined 
without delay', recognising difficulties caused through time-lags between a child's actions and legal processes. It is true that many of these rights are threatened for all children at this time, but the triple disadvantage for children involved in the justice system makes them much more vulnerable both to this erosion, and to poorer resultant outcomes.

The practical outworkings of pandemic-related policies also risk further disengaging and criminalising children in several ways, exacerbating this rights-threat. Lockdown could cause (or increase) difficulties in household relationships, recognised as potentially increasing childto-parent violence (YJB, 2020e; cf. Condry and Miles, 2012). Tough lockdown rules on behaviour and association with others may be more difficult for children involved in the justice system to maintain (given the over-representation of such conditions as Attention Deficit Hyperactivity Disorder and Conduct Disorder; cf. Silva et al., 2014), raising the distinct possibility of disproportionate legal action against children already involved in the justice system for breaching COVID-19 rules by meeting friends or leaving their home to avoid conflict.

Therefore, whilst several exceptional measures have been put in place by the YJB (mainly in terms of communication and sharing of good practice), and YOTs' creatively adaptations, there still remain distinct and in-built disadvantages for children involved in the justice system in the community, increasing their likelihood of further criminalisation, and decreasing safeguards which YOTs normally maintain so assiduously.

\section{The pains and gains of COVID-19 in custody}

Fewer children are now detained in the secure estate ${ }^{9}$ than at any point during the last thirteen years, one of the 'gains' associated with the pandemic. These reductions have been taking place over the previous decade and further extended in 2020 and 2021. The secure estate population of children reduced by 239 (28\%) to 613 in February 2021 compared with

\footnotetext{
${ }^{9}$ Children sentenced to custody are held in one of three types of custodial institution: Secure Children's Homes ( $\mathrm{SCH}$, small units for younger more vulnerable children, including girls; run by local authorities), Secure Training Centres (STCs, larger units for less vulnerable children up to 17; privately run) and Young Offender Institutions (YOIs, larger more prison-like units for boys between 15 and 18, generally run by the Youth Custody Service and holding the vast majority of children in custody). These distinctions explored more fully elsewhere (e.g. Bateman, 2020; XXX, 2020). Note that SCHs are inspected by Ofsted/Estyn rather than HMIP and due to anonymisation of reports, operational information is difficult to access.
} 
twelve months before (HM Prison and Probation Service, 2021) ${ }^{10}$, further dropping to 511 by September 2021 (MoJ, 2021). However, these decreases are not attributable to the Government's temporary early release scheme, since no child apparently met the criteria (MoJ, 2020d) $)^{11}$, in stark contrast to the other 37 countries which have found a way to facilitate this (UNICEF, 2021).

\section{Contact and access}

Contact with others is a basic human need, equivalent to food consumption or sleep. As Orben et al. (2020) explain, physical distancing is particularly harmful to teenagers who are at a unique developmental phase making socialising vital for brain development, identity construction and mental health. In the absence of face-to-face visits, it is therefore appropriate that children have been given increased phone credit and access to free helplines during the pandemic. YOIs rightly increased telephone credit, but by varying amounts (from £5-20; HMIP, 2020b) creating differential access. For example, children were grateful for extra phone credits but realised it might not be enough for all children:

"The worst part about being able to speak whenever you want, is that your credit goes... there's people I know that have zero pound credit... I do feel sorry for them because like they don't have family to support them...so they won't be getting enough money sent in." (Children's Commissioner, 2020: 9).

There is a strong case for extending best practice, including free phone and video calls, beyond the pandemic. For example, an inspection of HMYOI Feltham (February 2021) recommended that children/families should be actively supported in utilising video calls, which were 'underused, constituting a missed opportunity to support children maintain contact with their family and friends' (HMIP, 2021a: 5). Facilitating this requires a more flexible approach (HMIP, 2021b: 3). Digital interactions can mitigate lack of social contact for children in prison yet fully

\footnotetext{
${ }^{10}$ This compares with an average population approaching 3,000 in 2008/09 (Youth Justice Board for England and Wales).

${ }^{11}$ For children to be eligible, they had to be within 61 days of the end of their licence, their offence not on a list of excluded 'violent' offences, and had suitable accommodation available in advance. In response to the authors' Freedom of Information request, the Ministry of Justice explained that the scheme was only intended to reduce overcrowding in the adult estate, contrary to YJB guidance citing it as part of the YCS strategy for reducing incarceration (YJB, 2020b).
} 
enabling video conferencing (so called 'purple visits') has been slow, partly because children find the enforced presence of staff inhibiting (HMIP, 2020b). However, consequential absence of familial support is, as one child has put it: 'the hardest thing I've gone through' (Children's Commissioner, 2020: 8). Video calls cannot compensate for lost in-person visits, which were halted during the lockdowns, but their swifter introduction would have helped ease the impact on children. The Children's Commissioner (2020: 8) noted that in Oakhill STC, for example, available capacity for Skype visiting was not matched by plans to use it in practice.

\section{Innovation - benefits and risks}

Amidst heightened pains of imprisonment for children during the pandemic (Bateman, 2020), some institutions found innovative ways ('gains') to improve aspects of custody and mitigate the harshest pains of isolation, thus supporting children and strengthening links between health care, criminal justice and government agencies, with potential long-lasting benefits (Hewson et al., 2020). To relieve boredom for children spending extended time alone in cells, some institutions delivered additional in-cell activities. For example, Werrington, Cookham Wood, Feltham and Parc YOIs provided games consoles and DVD players, or made additional television channels available (Children's Commissioner, 2020). An inspection of HMYOI Feltham A found health services generally good, with few clinic waiting lists, particularly the dental service (HMIP, 2021a). However, it also acknowledged its parlous state at the time of the previous inspection (July 2019), where outcomes for children were so poor that the urgent notification protocol was invoked.

Children at Feltham reported that being unlocked in smaller groups of four during the pandemic had been effective for accessing education and other activities (HMIP, 2020a). Inspectors found that small groups had improved the quality of relationships between children and staff, with more children than previously reporting feeling cared for (56\% compared with $19 \%$ at the previous inspection) or encouraged to attend education ( $71 \%$ compared with $37 \%)$. Self-harm reduced dramatically with only five incidents recorded in the previous six months compared with 242 in the same period before the previous inspection (HMIP, 2021a: 3). However, some children thought that violence and bullying had not been dealt with effectively by staff prior to the pandemic, welcoming time away from others. Inspectors warned that 'violence, bullying and intimidation' have not disappeared, but manifested in different ways (HMIP, 2020a: 10). Despite decreases in violent incidents at 
HMYOI Feltham, one in five children still felt unsafe at the time of inspection. This was similar to a pre-pandemic inspection undertaken in $2019^{12}$ and there was a 'concerning rise in multiperpetrator assaults as friction between different groups increased' (HMIP, 2021a: 3).

Secure Children's Homes comprise smaller institutions holding fewer children, with higher staff to child ratios, so the worst effects of the pandemic were possibly easier to mitigate. For example, an interim inspection of Adel Beck SCH found that the impact of the pandemic had been managed very well, retaining its 'outstanding' rating. Children had been '...very well supported through their initial periods of isolation and have continued to receive consistent, stable care throughout this challenging time' (Ofsted, 2021: 1). Furthermore, children were found to have made 'significant developmental progress' (Ofsted, 2021: 1). In contrast, an unannounced joint inspection of Oakhill STC in September 2021 resulted in an urgent notification being issued (HMIP 2021c). Children's 'very poor' day-to-day experiences, including high levels of violence, use of force and single separation, were associated with pandemic-related low staffing levels and staff morale.

\section{Safeguarding}

HMPPS gave too little attention, especially initially, to distinct needs of children in custody, despite most meeting the definition of a vulnerable child (Chief Inspector of Prisons, 2021: 70). The Chief Inspector's annual report (addressing YOIs and STCS) also noted how leaders in public sector YOIs had tried to meet the needs of children safely, but were undermined by national HMPPS decisions to treat children similarly to adult prisoners (HM Chief Inspector of Prisons, 2021).

Pandemic restrictions have exacerbated some safeguarding issues already existent through generally deleterious effects of imprisonment (Goldson, 2005). For example, the Justice Select Committee hearing found pandemic-related problems were insufficient to explain the neglect of longstanding issues at Rainsbrook STC negatively impacting the lives of children (UK Parliament, 2021), such as being locked in cells for over 23 hours daily. Senior staff were failing to safeguard children, indicating the need for substantial improvements in governance and

\footnotetext{
12 During the July 2019 inspection period $40 \%$ of children said they had felt unsafe whilst at Feltham and $16 \%$ felt unsafe at the time of the inspection.
} 
accountability. The Committee proposed that Rainsbrook STC should be taken back 'in house', if promised improvements fail to materialise (UK Parliament, 2021).

Of course, children's experience of prison during the pandemic has not been uniform, due in part to considerable differences in practice between institutions, identified in the Children's Commissioner report (2021). Notably, the pandemic has compounded underlying structural issues of unequal treatment of ethnic minority children in the secure estate, impacting the extent to which these children can exercise their rights and be safeguarded (Tsintsadze, 2021). Ethnic minority children have consistently reported discriminatory treatment and more negative perceptions of imprisonment than their white counterparts. The 2019-20 Children in Custody report found that $42 \%$ of children surveyed reported experiencing victimisation and significantly increased likelihood of reporting verbal abuse or being or threatened/intimidated by staff (HMIP, 2021b). Children from minority ethnic backgrounds are also disproportionately likely to be subject to isolation in prison (Children's Commissioner, 2015). The use of segregation in child custody was already widespread prior to the pandemic; one third of children in prison spend time in isolation, prompting the Supreme Court to highlight the 'well known' risks of prolonged solitary confinement (longer than 15 days) as particularly harmful (R vs Secretary of State for Justice, 2015), but exacerbated during the lockdowns (Children's Commissioner, 2020). A challenge for the secure estate post-pandemic is to ensure children have more hours of constructive out-of-cell activity (HM Chief Inspector of Prisons, 2021:70).

\section{Children's rights}

During lockdown, children spent significantly more time locked up alone in cells (Children's Commissioner, 2020). Isolation appeared effectively normalised for children in custody during Covid-19 through increased time in cells (over 23 hours per day) and little contact with others, mimicking solitary confinement (Hewson et al., 2020). Even short periods in segregation are associated with poor psychological outcomes, including anger, depression, anxiety, paranoia, psychosis, and exacerbation of underlying mental illness (Shalev and Edgar, 2015). It is likely, therefore, that the mental health impact of the lockdown measures will persist beyond the measures themselves, also adversely affecting subsequent reintegration into society (UNCRC Article 40, UN, 1989; Alliance for Youth Justice, 2021). 
Children's right to access education (UNCRC Articles 28 and 29, UN, 1989) is an area of acute concern in custody; with engagement in education central to the development of positive, trusting relationships, constructive interactions with adults and enhanced capacity for behaviour management (Prisoner's Education Trust, 2016). Pre-pandemic regulations require that children receive a weekly minimum of 25-30 hours' education, depending on the type of custodial provision (Houses of Parliament, 2016). While government has previously claimed to be putting education at 'the heart of youth custody' (Houses of Parliament, 2016: 1), it frequently falls short, being generic, un/disengaging, and isolationist (XXX, 2020); there continues to be a need for a stronger, more holistic, approach to education for children in custodial environments (XXX, 2018; 2020).

Release on Temporary Licence (ROTL) ${ }^{13}$ has been contentious for some time in its lack of use with children, despite clear benefits for resettlement planning and post-custody outcomes (XXX; Hazel and Liddle, 2013), potentially threatening children's rights in custody (notably the principle of 'best interests' in Article 3; UN, 1989). It was concerning that reporting on ROTL was not even mentioned in the vast majority of inspections through the pandemic and reported as being entirely absent at Feltham A (HMIP, 2021a). Whilst use of ROTL has been at best faltering in the past, it seems to be a casualty of COVID-19 retrenchment.

Pandemic constraints have contributed to a custodial environment in which children's health and well-being is threatened, further contributing to their 'arrested development' (Dmitrieva et al., 2012; Children's Commissioner, 2020). It is unsurprising that YOIs and STCs were illequipped to meet the needs of incarcerated children, as they were already characterised by high levels of violence, low staff-child ratios and little meaningful time out of cells before the pandemic (Bateman, 2016; Taylor, 2016; Youth Custody Improvement Board, 2017).

There is an opportunity for a smaller, better resourced secure estate following the pandemic (Bateman 2020), notably through further reducing the use of imprisonment for children in England and Wales to better align policy and practice with the UNCRC (AYJ, 2020; Harris and Goodfellow, 2021). Lessons can be learnt from institutions which successfully mitigated the harmful effects of lockdown. Relatedly, the Children's Commissioner for England (2021) has

\footnotetext{
13 Temporary release from prison (YOIs and STCS) for a short period of time - usually a day - to improve resettlement planning (XXX). In SCHs it is called 'mobility'.
} 
called for the YCS to better understand the welfare needs of the children held in custody across the jurisdiction.

\section{Into the future...the continuing pains and emerging gains of COVID-19?}

Whilst the initial lockdown of Spring 2020 managed to address the initial spread of the virus, infection rates subsequently developed into a second wave, prompting further lockdowns across Europe (Buchholz, 2021) and demonstrating prematurity in the YJB's 2020 summer 'recovery plan' (YJB, 2020f). A European 'third wave', despite widespread vaccine roll-outs, also indicates that the issues highlighted by the pandemic will not be quickly overcome (Elflein, 2021). Lessons have been learnt in the YJS from the first lockdown experience, reflected in changes to legislation and policy to mitigate the potentially iatrogenic, criminalising and disengaging effects of systemic restrictions and related delays to justice and breaches of children's rights. Indeed, a thematic review of youth offending services (November 2020) concluded that following the onset of COVID-19, youth justice 'leaders and managers at a local and partnership level responded quickly to the needs of children...[through] innovation, care and commitment' (HMIP, 2020a: 7). Certain rules are no longer as restrictive - for example, there was not the same shutdown of courts and educational establishments during the second wave of lockdown (in)activity (Winter 202021). This helped avoid further delays to justice, circumventing potential disengagement and neglect of children through the removal of service provision and support. In this second wave lockdown, whilst 'purple visits' in custody potentially provided flexibility (particularly to professionals), face-to-face visits for incarcerated children were no longer proscribed, demonstrating understanding of the different needs of children (as opposed to adults, for whom visits were again curtailed). Furthermore, YOTs are now better equipped to extend work begun in the first lockdown, incorporating new innovations into practice, so community contact by video call can continue without hiatus (whilst the most vulnerable still receive faceto-face visits), and virtual methodologies for conducting such processes as Referral Order Panel meetings online can continue. The vaccine roll-out has also re-established increasing face-to-face work with vulnerable children, as YOT workers were early recipients. Potentially these gains of COVID-19 can become part of the 'new normal' of youth justice working, encouraging more out-of-office working, encompassing creative methods epitomised by 
allotment-based appointments and 'walk and talk' contacts (HMIP, 2020a), which could boost YJB aims in actualising Child First youth justice into practice.

Not all innovative, supportive and mitigating measures have been pursued consistently or successful, however, with inadequate IT particularly proving a significant barrier to effective engagement in terms of contact, assessment, relationship-building and access to education. Whilst face-to-face education was quickly re-established in most SCHs and STCs, YOIs continued to fail their children by their slow action, exacerbating already-identified difficulties in addressing children's access to sufficient educational provision (HMIP, 2020a). Video call contacts are now established practice within most YOTs and custodial institutions, but the relatively low take-up for this facility has not been adequately addressed, particularly amongst those children (not to mention YOTs and especially custodial establishments) with difficulties in IT access, indicative of a 'digital divide' that continues to exclude and disengage socially disadvantaged children in the YJS from appropriate levels of contact with staff and access to education (HMIP, 2020a: 25). With no clear plans for improving this, the potential of this facility for providing a real alternative to face-to-face visits, when these are not possible, could be missed. Finally, the inspection reports, whilst commenting that extra phone credit allowances given to children in custody are inexplicably uneven and unfair, did not take the opportunity to suggest that charges should be waived for this basic essential. Taken together, it seems that although the world is to some extent getting used to operating under COVID-19 restrictions, children involved in the justice system continue to be relatively poorly served and significantly disengaged by resultant policies and practice in England and Wales. The pandemic could be a catalyst for long overdue improvement, eradicating the worst systemic harms. However, to date there has been little appetite for the decisive action required to make changes to achieve this.

In terms of its impact on developing Child First justice (as the YJB's 'strategic approach and central guiding principle'), COVID-19 and related policy/practice developments have had a mixed effect, potentially damaging its fledgling acceptance across YJS agencies. The first tenet (seeing children as children) has been eroded through adult-focused justice actions being applied to children (especially through the lack of/delayed court action, causing children who reached the threshold of adulthood with no first court date in sight being tried eventually as adults and sentenced using adult sentencing guidelines), the increased impact of delays to 
justice on children (than adults) and through the side-lining of children's rights such as 'best interests' forming the heart of policy in favour of expediency. However, drops in custody use throughout the pandemic is definitely beneficial, given long-standing concerns over the damage this causes, thereby forcing better consideration within sentencing (and remand decisions) of 'best interests'.

The second tenet (developing a prosocial identity for positive child outcomes) emphasises the importance of relationships between YOT workers and children - some of the innovations from YOTs (like 'walk and talk') may have better facilitated deeper relationships, making it vital that new creative ways of working are not lost as 'normal' working practices are refound. Children who have appreciated greater use of technology in this field likewise may have felt more able to develop; however, the various reports to which we have referred identified an issue with digital poverty - not all children have adequate access (even if given hardware, they may have had no home internet access), emphasising differential access to justice according to socio-economic status. This retraction from wider social inclusion also threatens tenet 3 (collaborating with children), as children who are less accessible (potentially the case when not seen in person) are likely to have reduced opportunities to fully contribute and be heard, illustrated by difficulties voiced concerning virtual Referral Order panels. It was unclear whether any court procedures for children were undertaken virtually as no information on this was centrally recorded, but it is difficult to imagine that children would feel more confident in speaking online and may well approach this in a detached game-playing manner, lacking reality.

The final tenet (promoting diversion) is a double-edged sword - reduced contact caused by lack of programmes for children not on statutory orders could potentially fit this tenet, as it represents less intervention. However, if prevention services steering children away from formal system contact were not there (potentially being run by non-criminal organisations, like youth services, and therefore not in any sense criminalising; but current funding issues makes this unlikely in practice), it is possible that more children would be drawn into the formal YJS. Children on formal court-ordered contact being seen less frequently could also be seen similarly - contact reduction could be beneficial, unless it results in complex needs not sufficiently met, or insufficient time for supportive relationships to be build between child and YOT worker. 
It therefore becomes even more important that the effects of COVID-19 process and practice changes are observed to see what is truly beneficial and worth keeping, and what damaging aspects need to fall away or be actively addressed as the pandemic subsides. Only then will it be clearer what have, in reality, been the pains and gains of COVID-19.

\section{References}

Alliance for Youth Justice/AYJ (2020) Ensuring custody is the last resort for children in England and Wales. Available at: https://static1.squarespace.com/static/5f75bfbbfb67fc5ab41154d6/t/5fb397c29c9013373f 64138d/1605605317603/Ensuring+custody+is+the+last+resort.pdf (accessed 12 April 2021).

Barn R and Barn B (2019) Youth Justice in the Digital Age: A Case Study of Practitioners' Perspectives on the Challenges and Opportunities of Social Technology in Their TechnoHabitat in the United Kingdom, Youth Justice, Vol. 19(3): 185-205

Bateman, T. (2016) The State of Youth Custody. The National Association for Youth Justice https://thenayj.org.uk/wp-content/uploads/2016/10/NAYJ-Briefing-State-of-Youth-Custody2016.pdf (accessed 12 November 2021)

Bateman T (2020) Unjust pains: the impact of COVID-19 on children in prison. Journal of Children's Services. Available at: www.emerald.com/insight/content/doi/10.1108/JCS-072020-0045/full/html (accessed 15 April 2021).

BBC (2020) Coronavirus: Strict new curbs on life in UK announced by PM, BBC News, 24 March 2020. Available at: www.bbc.co.uk/news/uk-52012432 (accessed 23 July 2020).

Buchholz K. (2021) Europe Stays in Lockdown Mode. In: Statista blog Coronavirus disease (COVID-19) pandemic. Available at: https://www.statista.com/chart/23330/coronavirusrestrictions-europe-map/ (accessed 28 May 2021).

$X X X$

XXX

$X X X$ 
$X X X$

Children's Commissioner (2015) Unlocking Potential. Available at: www.childrenscommissioner.gov.uk/report/unlocking-potential/ (accessed 12 April 2021).

Children's Commissioner (2020) Children in custody. Briefing, May 2020. Available at: www.childrenscommissioner.gov.uk/wp-content/uploads/2020/05/cco-children-in-

custody.pdf (accessed 28 May 2021).

Children's Commissioner (2021) Briefing: Children in custody during lockdown. February 2021. Available online at www.childrenscommissioner.gov.uk/wp-content/uploads/2021/02/ccochildren-in-custody-during-lockdown.pdf (accessed 22 November, 2021).

Condry R and Miles C (2010) Adolescent to Parent Violence and Youth Justice in England and Wales. Social Policy and Society, 11(2): 241-250.

Dmitrieva J, Monahan KC, Cauffman E and Steinberg L (2012) Arrested development: The effects of incarceration on the development of psychosocial maturity. Development and Psychopathology 24: $1073-1090$.

Ealing Integrated Youth Service (2020) Contingency Plan-March / April 2020. Available online at

https://yjresourcehub.uk/component/k2/item/download/885 8c5a20f873ff99d201bfca9c0 43fd92b.html (accessed 26 November 2021).

Elflein J. (2021) Coronavirus (COVID-19) disease pandemic- Statistics \& Facts. Available at: www.statista.com/topics/5994/the-coronavirus-disease-covid-19-outbreak/ (accessed 28 May 2021).

Goldson B (2005) Child Imprisonment: A Case for Abolition. Youth Justice 5(2): 77-90.

Goldson, B (2014) Youth Justice in a Changing Europe: Crisis Conditions and Alternative Visions'. Perspectives on Youth 1: 39-52.

$x X X$

$X X X$ 
Harris, M and Goodfellow, P (2021) The Youth Justice System's Response to the Covid-19 pandemic - Literature Review, July 2021. The Alliance for Youth Justice. https://www.ayj.org.uk/news-content/covid-project-literature-review $\quad$ (accessed 12 November 2021)

Hazel N and Liddle M (2013) Resettlement in England and Wales: Key Policy and Practice Messages. London: YJB

Hazel N and Bateman T (2021) Supporting children's resettlement ('reentry') after custody: beyond the risk paradigm. Youth Justice 21(1): 71-89.

Hazel N, Goodfellow P, Liddle M, Bateman T and Pitts J (2017) Now All I Care about Is My Future': Supporting the Shift - Framework for the Effective Resettlement of Young People Leaving Custody. London: Nacro. Available at: www.beyondyouthcustody.net/wpcontent/uploads/Now-all-I-care-about-is-my-future-Supporting-the-shift-full-researchreport.pdf (accessed 28 May 2021).

Hewson T, Shepherd A, Hard J and Shaw J (2020) Effects of the COVID-19 pandemic on the mental health of prisoners. The Lancet Psychiatry 7(7): 568-570.

HM Chief Inspector of Prisons for England and Wales (2017) Annual Report 2016-17. Available at: www.gov.uk/government/uploads/system/uploads/attachment data/file/629719/hmipannual-report-2016-17.pdf (accessed 28 May 2021).

HM Chief Inspector of Prisons (2021) Annual Report 2020-21 https://www.justiceinspectorates.gov.uk/hmiprisons/wpcontent/uploads/sites/4/2021/07/6.7391 HMI-Prisons Annual-Report-and-Accounts202021 v6.1 WEB.pdf (accessed 12 November 2021)

HMIP (2020a) A thematic review of the work of youth offending services during the pandemic. Available at: $\quad$ www.justiceinspectorates.gov.uk/hmiprobation/wpcontent/uploads/sites/5/2020/11/201110-A-thematic-review-of-the-work-of-youthoffending-services-during-the-COVID-19-pandemic.pdf (accessed 12 April 2021). HMIP (2020b) Report on short scrutiny visits to Young offender institutions holding children, 21 April 2020. Available at: www.justiceinspectorates.gov.uk/hmiprisons/wpcontent/uploads/sites/4/2020/05/YOIs-SSV-Web-2020.pdf (accessed 20 July 2020). 
HMIP (2021a) Report on a scrutiny visit to HMYOI Feltham A by HM Chief Inspector of Prisons, 9 and 17 February 2021. Her Majesty's Inspectorate of Prisons. Available at: www.justiceinspectorates.gov.uk/hmiprisons/inspections/hmyoi-feltham-a/ (accessed 12 April 2021).

HMIP (2021b) Children in Custody 2019-20 - An analysis of 12-18-year-olds' perceptions of their experiences in secure training centres and young offender institutions. Her Majesty's Inspectorate of Prisons. Available at: www.justiceinspectorates.gov.uk/hmiprisons/wpcontent/uploads/sites/4/2021/02/CYP-report-2019-20-web.pdf (accessed 12 April 2021).

HMIP (2021c) Unannounced Monitoring Visit of Oakhill Secure Training Centre jointly by Care Quality Commission, HMIP and Ofsted. October 2021. Her Majesty's Inspectorate of Prisons https://files.ofsted.gov.uk/v1/file/50170360 (accessed 12 November 2021)

HM Prison and Probation Service (2021) HM Prison and Probation Service COVID-19 Official Statistics Data to 31 January 2021. Published 12 February 2021. Available at: https://assets.publishing.service.gov.uk/government/uploads/system/uploads/attachment data/file/960361/HMPPS COVID19 JAN21 Pub Doc.pdf (accessed 12 April 2021).

House of Commons Justice Committee (2020a) Coronavirus (COVID-19): The impact on courts. Available

at https://committees.parliament.uk/publications/2188/documents/20351/default/ (accessed 28 May 2021).

House of Commons Justice Committee (2020b) Children and Young People in Custody (Part 1): Entry into the youth justice system. Available at: https://publications.parliament.uk/pa/cm5801/cmselect/cmjust/306/30602.htm (accessed 12 November 2020).

Houses of Parliament (2016). Education in Youth Custody. POSTNote Number 524. Available at: $\quad$ http://researchbriefings.files.parliament.uk/documents/POST-PN-0524/POST-PN0524.pdf (accessed 28 July 2020).

Johns DF, Williams K, and Haines K (2017) Ecological Youth Justice: Understanding the Social Ecology of Young People's Prolific Offending. Youth Justice 17(1): 3-21.

$X X X$ 
$X X X$

Lundy L, Byrne B, Lloyd K, Templeton M, Brando N, Corr M, Heard E, Holland L, MacDonald M, Marshall G, McAlister S, McNamee C, Orr K, Schubotz D, Symington E, Walsh C, Hope K, Singh P, Neill G, and Wright LHV (2021) Life Under Coronavirus: Children's Views on their Experiences of their Human Rights, The International Journal of Children's Rights, Vol. 29(2): 261-285

Lynch N, and Kilkelly U (2021) "Zooming In" on Children's Rights During a Pandemic: Technology, Child Justice and covid-19, The International Journal of Children's Rights, Vol. 29(2): 286-304

McAra L and McVie S (2007) Youth Justice? The Impact of System Contact on Patterns of Desistance from Offending. European Journal of Criminology 4(3): 315-345.

Ministry of Justice/MoJ (2020a) Coronavirus (COVID-19): courts and tribunals planning and preparation. Available at: www.gov.uk/guidance/coronavirus-covid-19-courts-and-tribunalsplanning-and-preparation\#history (accessed 28 May 2021).

Ministry of Justice (2020b) Coronavirus (COVID-19) and Prisons. Available at: www.gov.uk/guidance/coronavirus-covid-19-and-prisons (accessed 28 May 2021).

Ministry of Justice (2020c) Youth Justice Statistics 2019-2020. Available at: https://assets.publishing.service.gov.uk/government/uploads/system/uploads/attachment data/file/956621/youth-justice-statistics-2019-2020.pdf (accessed on 28 May 2021).

Ministry of Justice (2020d) End of Custody Temporary Release. Available at: https://assets.publishing.service.gov.uk/government/uploads/system/uploads/attachment data/file/881061/end-custody-temporary-release.pdf (accessed 28 May 2021).

Ministry of Justice (2021) Youth Custody Report: September 2021. Available at https://assets.publishing.service.gov.uk/government/uploads/system/uploads/attachment data/file/1032554/youth-custody-report-september-2021.xlsx (accessed 30 November 2021) MoJ/YJB (2019) Standards for children in the justice system 2019. Available at: https://assets.publishing.service.gov.uk/government/uploads/system/uploads/attachment 


\section{data/file/957697/Standards for children in youth justice services 2019.doc.pdf} (accessed 28 May 2020).

NPCC (2015) Child-centred Policing. Available at: www.npcc.police.uk/documents/edhr/2015/CYP\%20Strategy\%202015\%202017\%20August \%202015.pdf (accessed 28 May 2021).

Ofsted (2021) Interim inspection of Adel Beck Secure Children's Home, October 2021. Available at https://files.ofsted.gov.uk/v1/file/50172057 (accessed 12 November 2021)

ONS (2020) Labour market overview, UK: September 2020. Available at: www.ons.gov.uk/employmentandlabourmarket/peopleinwork/employmentandemployeety pes/bulletins/uklabourmarket/september2020 (accessed 2 April 2021).

Orben A, Tomova L and Blakemore S (2020) The effects of social deprivation on adolescent development and mental health. The Lancet Child and Adolescent Health 4: 634-640.

Pitt S (2018) The greatest pandemic in history. The Bio-medical Scientist blog. Available at: https://thebiomedicalscientist.net/science/greatest-pandemic-history $\quad$ (accessed 19 November 2020).

Prisoners' Education Trust (2016) Great expectations: Towards better outcomes for young people and young adults in custody. London: Prisoners' Education Trust. Available at: www.prisonerseducation.org.uk/wp-content/uploads/2019/04/Great-Expectations-ReportFinal.pdf (accessed 28 May 2021).

$R \quad v$ Secretary of State for Justice (2015) UKSC 54 https://howardleague.org/wpcontent/uploads/2016/05/3 -

$\mathrm{R}$ on the application of Bourgass and another $\vee$ Secretary of State for Justice.pdf (accessed 12 April 2021).

Sentencing Council (2017) Sentencing Children and Young People. Available at: www.sentencingcouncil.org.uk/wp-content/uploads/Sentencing-Children-and-Young-

People-definitive-guideline-Web.pdf (accessed 28 May 2021).

Shalev S and Edgar K (2015) Deep custody: segregation units and close supervision centres in England and Wales. London: Prison Reform Trust. Available from: 
www.prisonreformtrust.org.uk/Portals/0/Documents/deep custody 111215.pdf (accessed 12 April 2021).

Silva D, Colvin L, Glauert R and Bower C, (2014) Contact with the juvenile justice system in children treated with stimulant medication for attention deficit hyperactivity disorder: a population study. The Lancet Psychiatry 1(4): 278-285.

Sleight D (2020) Justice delayed is justice denied for clients in lockdown limbo. The Law Society Gazette, 13 November, 2020. Available at: www.lawgazette.co.uk/commentary-andopinion/justice-delayed-is-justice-denied-for-clients-in-lockdown-limbo/5106414.article (accessed 28 May, 2021).

Sykes GM (1958) The Society of Captives: A Study of a Maximum Security Prison. Princeton: Princeton University Press.

Taylor C (2016) Review of the Youth Justice System in England and Wales. Available at: https://assets.publishing.service.gov.uk/government/uploads/system/uploads/attachment data/file/577103/youth-justice-review-final-report.pdf (accessed 28 May 2021).

Tsintsadze K (2021) A record of our own - lockdown experiences of minority ethnic prisoners. Zahid Mubarek Trust. Available at: https://thezmt.org/2021/03/31/a-record-of-our-ownlockdown-experiences-of-ethnic-minority-prisoners/ (accessed 28 May 2021).

UK Government (2021) Coronavirus (COVID-19) in the UK. Available at: https://coronavirusstaging.data.gov.uk/ (accessed 28 May 2021).

UK Parliament (2021) Justice Select Committee hearing, Rainsbrook Secure Training Centre, 29 March 2021. Available at: https://publications.parliament.uk/pa/cm5801/cmselect/cmjust/1266/126604.htm\# idText Anchor002 (accessed 12 April 2021).

UNICEF (2021) Access to Justice for Children in the era of COVID-19: Learnings from the Field. Available at www.unicef.org/media/92261/file/Access-to-Justice-COVID-19-Learning-Brief-2021.pdf (accessed 30 November 2021) 
United Nations/UN (1989) Convention on the Rights of the Child. Available at: www.ohchr.org/EN/Professionallnterest/Pages/CRC.aspx (accessed on 17 March 2021).

United Nations (2020) COVID-19 and Human Rights. We are all in this together. Available at: www.un.org/victimsofterrorism/sites/www.un.org.victimsofterrorism/files/un human rights and covid april 2020.pdf (accessed 28 May 2021).

Wrexham Youth Justice Service (2020) COVID-19 Contingency Plan - Wrexham Youth Justice Service. Available at https://yjresourcehub.uk/covid-19-resources-for-youthjustice/item/download/874 947982a74714454e97d7756ceba45829.html laccessed 10 November 2021)

Yates J (2010) Structural Disadvantage: Youth, Class, Crime and Poverty. In Taylor W, Earle R and Hester R (eds) Youth Justice Handbook: Theory, Policy and Practice. Abingdon: Routledge, pp.5-22.

YJB (2018) How to make resettlement constructive. Available at: https://yjresourcehub.uk/custody-andresettlement/item/download/723 b535da3b3f0716677b9964ec93870ca6.html (accessed 28 May 2021).

YJB (2019) Case Management Guidance. Available at: www.gov.uk/government/collections/case-management-guidance (accessed 28 May 2021). YJB (2020a) Youth Justice Board update on COVID-19. Available at: www.gov.uk/government/news/youth-justice-board-update-on-covid-19 (accessed 18 October 2020).

YJB (2020b) Youth Justice Partner COVID-19 Update. Available at: https://yiresourcehub.uk/covid-19-resources-for-youthjustice/item/download/852_458b6afb3bcb42adcbfbf1ef0592940e.html (accessed 20 October 2020).

YJB (2020c) Good Practice in Youth Justice during the COVID-19 Pandemic in Wales. Available at: https://viresourcehub.uk/covid-19-resources-for-youthjustice/item/download/933 5acf0a5bffe72aea68e11d79d772593d.html $\quad$ (accessed 2 November 2020). 
YJB (2020d) COVID-19: Resources for youth justice. Available at: https://yjresourcehub.uk/covid-19-resources-for-youth-justice.html (accessed 31 October 2020).

YJB (2020e) Child to Parent Violence. Available at: https://yjresourcehub.uk/covid-19resources-for-youth-justice/item/688-child-to-parent-violence.html (accessed 1 November 2020).

YJB (2020f) COVID-19 Recovery Plans: guidance for youth offending teams. Available at: https://assets.publishing.service.gov.uk/government/uploads/system/uploads/attachment_ data/file/899450/COVID-19_YJB_Recovery_Guidance_for_YOTs.pdf (accessed 29 March 2021).

YJB (2021a) Business Plan 2021-2022. Available at: https://assets.publishing.service.gov.uk/government/uploads/system/uploads/attachment data/file/974575/YJB Business Plan 2021-22.pdf (accessed 28 May, 2021).

YJB (2021b) Strategic plan 2021-2024. Available at: https://assets.publishing.service.gov.uk/government/uploads/system/uploads/attachment data/file/966200/YJB Strategic Plan 2021 - 2024.pdf (accessed 28 May 2021).

YMCA (2020) Out of Service. Available at https://www.ymca.org.uk/wpcontent/uploads/2020/01/YMCA-Out-of-Service-report.pdf (accessed 26 November 2021). https://www.ymca.org.uk/wp-content/uploads/2020/01/YMCA-Out-of-Service-report.pdf Youth Custody Improvement Board (2017) Findings and Recommendations. Available at www.gov.uk/government/publications/youth-custody-improvement-board-findings-andrecommendations (accessed 12 November 2021)

Youth Custody Service (2021) Monthly Youth Custody Report - February 2021. Available at: www.gov.uk/government/statistics/youth-custody-data (accessed 12 April 2021).

Zettler H (2021) Much to Do About Trauma: A Systematic Review of Existing Trauma-Informed Treatments on Youth Violence and Recidivism. Youth Violence and Juvenile Justice 19(1): 113134. 